\title{
Efforts to Increase Mathematical Logical Intelligence Through Development of Student Worksheets Based on Problem Based Learning
}

Prahasti Cynthia Hardiyanti ${ }^{凶}$, Sri Wardani, Cepi Kurniawan

Pascasarjana, Universitas Negeri Semarang, Indonesia

\begin{tabular}{|c|c|}
\hline Article Info & Abstract \\
\hline $\begin{array}{l}\text { Article History : } \\
\text { Received January } 2020 \\
\text { Accepted February } 2020 \\
\text { Published December } 2020\end{array}$ & \multirow{3}{*}{$\begin{array}{l}\text { Chemistry is a subject that is closely related to learning that requires students } \\
\text { to be active in problem solving. Because of this, a worksheet development is } \\
\text { needed to support chemistry learning activities. This research aims to develop } \\
\text { a Student Based Worksheet (LKPD) based on Problem Based Learning (PBL) } \\
\text { hydrolysis material to improve mathematical logical intelligence. The quality } \\
\text { of LKPD is measured by the criteria of validity, effectiveness, and practicality } \\
\text { in the learning process. The development model used in this research is a 3D } \\
\text { model (define, design and develop). Data analysis techniques using } \\
\text { qualitative and quantitative tests. The product development validation was } \\
\text { carried out by the validator of media experts and material experts, while the } \\
\text { trial was conducted by } 36 \text { students of class XI IPA } 5 \text {. The results of the } \\
\text { validator analysis stated that the quality of learning material was included in } \\
\text { the excellent category with a percentage of } 93.77 \% \text { of the material experts and } \\
94.46 \% \text { of media experts. The effectiveness of LKPD indicated an increase in } \\
\text { mathematical logical intelligence of students with the achievement of N-gain } \\
\text { of } 0.56 \text { in the medium category and classical completeness of } 86.11 \% \text {. Student } \\
\text { responses to the practicality of using LKPD showed results of } 77.78 \% \text { which } \\
\text { included in the very good category and } 22.22 \% \text { included in the good category. } \\
\text { Based on the results obtained, it can be concluded that LKPD fulfills valid, } \\
\text { effective, practical criteria, and can improve mathematical logical } \\
\text { intelligence. }\end{array}$} \\
\hline $\begin{array}{l}\text { Keywords: } \\
\text { Mathematical Logical } \\
\text { Intelligence; Student } \\
\text { Worksheet; Problem } \\
\text { Based Learning }\end{array}$ & \\
\hline & \\
\hline
\end{tabular}

(C) 2020 Universitas Negeri Semarang

$凶$ correspondence:

Pascasarjana, Universitas Negeri Semarang

p-ISSN 2252-6412

Jalan Kelud Utara III No. 37 Semarang, Jawa Tengah, Indonesia

e-ISSN 2502-4523

50237

E-mail: cynthiaprahasti@gmail.com 


\section{INTRODUCTION}

Along with the development of progress in all aspects of life, humans are required to always be active and dynamic in facing all the changes that occur, including education aspects. This is what makes the Indonesian government reference to continue to evaluate the education system, one of which is through the implementation of the 2013 curriculum. Learning with the 2013 curriculum can be realized by emphasizing modern pedagogic through a scientific approach (Rosita et al., 2014). The approach focuses on involving active students in learning activities through a scientific thinking approach.

Learning activities with a scientific approach require the application of appropriate learning strategies so that they can be implemented well (Etiubon \& Ugwu, 2016). This learning can train the activeness and independence of students to be able to construct their knowledge independently based on existing media or learning resources. One of the learning resources used is the Student Worksheet (LKPD). In this case, LKPD's role is to complement the material taught and exercises to improve students' understanding of the material presented (Asiyah et al., 2013). LKPD is used by to optimize the involvement of students in learning. Broadly speaking, LKPD is one source of teaching that can be used to support learning activities by involving the participation of students.

Based on observations and interviews conducted on October 9, 2018 with Semarang 6 High School teachers, it was explained that chemistry learning activities were supported by the use of modules and LKPD from publishers appointed by schools. LKPD is used to provide materials and tasks simultaneously about the material being discussed (Prastowo, 2011). Teachers more often use LKPD because it is practical in learning activities. LKPD is used by teachers as one of the teaching resources to explain concepts and practice questions in solving chemical problems. In addition, LKPD is also used to conduct investigations or resolve problems (Haryani, et al., 2017). However, the existing LKPD only consisted of brief summaries of material and question exercises that did not include aspects of variations in learning activities, problem solving and students' understanding of chemistry lessons.
Chemistry Study Material in Senior High School is a relatively new material and is considered quite difficult for students (Ristiyani \& Evi, 2016). Chemical materials include concepts, chemical reactions and chemical calculations. Based on the results of previous studies, chemicals that are still considered difficult and confusing for students are salt hydrolysis (Boncel et al., 2017). The problem when teaching salt hydrolysis material is the difficulty of students when applying $\mathrm{pH}$ concepts and formulas to solve the given problem or problem. This is shown from the results of the evaluation of the material in the form of essay questions or descriptions, the majority of students do not work according to the steps of solving chemical material and tend to answer with the contents of short ways, especially for chemical count problems.

The problem-solving ability is related to the intelligence that exists in students. One theory of intelligence is multiple intelligences. Compound intelligence known as the multiple intelligences (MI) theory put forward by (Gardner, 2003) states that MI theory provides an alternative way for teachers to apply the best learning methods (Armstrong, 2013). One of the multiple intelligences related to problem solving is mathematical logical intelligence. Mathematical logical intelligence is the ability in terms of logic and numbers (Purnomo \& Novita, 2018). Mathematical logical intelligence is the ability in a person to solve problems related to mathematical reasoning numbers. Indicators of logical-mathematical intelligence include problem solving, sharpness of abstract patterns (thinking patterns), calculation processes (logical processes), logical analysis and mathematical operations (Lazear, 2004).

Chemical materials mostly include calculation materials such as salt hydrolysis material. This can not be separated from the activity of analysis, counting and reasoning. Therefore, in learning hydrolysis material, mathematical logical intelligence is important to be developed because it can help students in solving mathematical problems mathematically. One learning that is expected to support the ability of students in solving problems is the Problem Based Learning (PBL) model. PBL can develop higher-order thinking skills, encourage them to describe what they already know, and integrate their knowledge in collaborative groups 
(Tarhan \& Acarsesen, 2013). PBL encourages students to find solutions to problems that are given can help to improve students' self abilities.

PBL model is a learning model that stimulates students to think about solving contextual problems (Mariani \& Kusumawardani, 2014). The development of LKPD is carried out in each sub-section of the subject which is associated with facts and natural phenomena that occur in the daily environment (Andriyantin et al., 2016). This can be poured into case examples, picture illustrations and sample problems with solutions, integration of PBL learning models and simple experiments to train independent students in solving problems in learning.

One way that teachers can do is to develop LKPD by applying learning models in their learning activities (Riyani et al., 2017). The learning model that can be applied is PBL. The application of PBL directs students to become accustomed to the provision of various contextual problems that require the ability to think and solve problems (Alejandro et al., 2010). Problem discourse aims to train students to develop problem-solving abilities through scientific stages (Surya \& Holiwarni, 2017). LKPD is prepared by giving references to students in the form of discourse on different problems and adapted to the sub-subject matter to be studied.

Based on related data and the results of preliminary observations, researchers are interested in developing PBL-based LKPD, on hydrolysis material to improve students' mathematical logical intelligence. The purpose of this study is to determine the validity of LKPD developed and used in the learning process, to find out whether LKPD is effective in improving students' mathematical logical intelligence, and to find out the practicality of LKPD that is developed if it is used in the learning process.

\section{METHODS}

This research is a type of R\&D (Research and Development) that refers to the $4 \mathrm{D}$ procedural model of (Thiagarajan, 1974) which is modified into $3 \mathrm{D}$. The stages in this model include the stages of defining (problem identification and observation) design (design) and development (development).

The study was conducted in Semarang 6 High School students of class XI Science. The types of data in this study include qualitative and quantitative data. The analysis includes LKPD validation, test question reliability, N-Gain test mathematical logical intelligence test, and response sheet analysis. The overall data collection techniques and instruments are presented in Table 1.

Table 1. Table of Techniques and Data Collection Instruments

\begin{tabular}{llll}
\hline Data type & Method Data Collection & Instrument Data Collection & Subject \\
\hline Prelimenery research & Interview and & Interview and questionnaire & Teacher and \\
& questionnaire & sheet & students \\
LKPD Validation & Validation & Validation sheet & Validator \\
Mathematical logical intelligences & Test & Test sheet & Students \\
Students responses questionnaire & Questionnaire & Questionnaire sheet & Students \\
\hline
\end{tabular}

\section{RESULTS AND DISCUSSION}

This research begins by identifying and gathering information about various conditions in the beginning of the learning process that takes place at school. The initial conditions include the handbook used as a reference in teaching, the learning methods used, the teacher's understanding of learning based on PBL application in the learning process, the teacher's understanding of multiple intelligences, one of which is mathematical logical intelligence, the efforts of teachers who do other than to improve to improve mathematical logical intelligence, and LKPD used in the learning process.

The next stage in this research is to compile and develop various research tools that are needed to then be validated to the experts. The validity category can be seen in Table 2 . The results of the material expert validation can be presented in Table 3 and the media expert validation in Table 4. 
Table 2. Validity Category

\begin{tabular}{ll}
\hline Score $(\%)$ & Criteria \\
\hline $80<\mathrm{x} \leq 100$ & Very valid \\
$60<\mathrm{x} \leq 80$ & Valid \\
$40<\mathrm{x} \leq 60$ & Enough \\
$20<\mathrm{x} \leq 40$ & Less valid \\
$0<\mathrm{x} \leq 20$ & Not valid \\
\hline
\end{tabular}

Table 3. Results of Expert Material Validation

\begin{tabular}{ll}
\hline Rated aspect & Percentage (\%) \\
\hline Content feasibility & 93.82 \\
Presentation feasibility & 96.53 \\
Language feasibility & 92.78 \\
\hline Overall percentage & 94.38 \\
\hline
\end{tabular}

Validation is done using a validation sheet that contains questions about various aspects of product eligibility. The validation sheet contains 27 question criteria using a scale of 1-4. The results of the validation assessment of 3 validators get a percentage of $94.38 \%$ which means they are included in the very valid criteria. This shows that the LKPD developed is suitable to be used as learning material.

Table 4. Media Expert Validation Results

\begin{tabular}{ll}
\hline Rated aspect & Percentage (\%) \\
\hline Size of LKPD & 95.83 \\
Cover design of LKPD & 94.04 \\
Content design LKPD & 93.51 \\
\hline Overall percentage & 94.46 \\
\hline
\end{tabular}

Validation is done using a questionnaire containing questions about various aspects of product eligibility. The questionnaire sheet contains

Fase 1. Orientasi Masalah

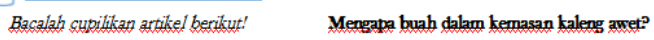

Pernahkah kalian membeli atau bahkan mengonsumsinya?

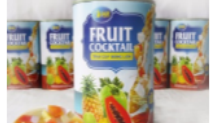
Buah-buahan dalam kaleng perlu dibubuhi asam sitrat dan natrium sitrat untulk menjaga $\mathrm{pH}$ agar tidal mudah rusal. Buah-buahan yang bisa disebut dengan larutan adalah buah yang mengandung asam sitrat. Asam sitrat merupakan assam organik lemah yang ditemukan pada daun dan byah tumbuhan genus Citrus (jerulk-jerukan). Senvara ini merupakan bahan pengawer yang baik dan alami, selain digunakan sebagai penambah rasa masam pada makanan dan minuman ringan. Gambar 4. Bugh balengan Keasaman asam sitrat didapatkan dari tiga gugus karboksil - $\mathrm{COOH}$ yang

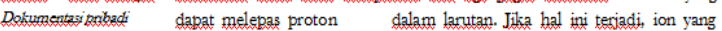
dihasillkan adalah ion sitrat. Sitrat sangat bail digunalan dalam larutan penxangga untulk mengendolithan $\mathrm{pH}$ larutang. Ion sittat dapat bereaksi dengan banxalk ion logam membentulk garam sitrat. Reaksi.reakss biokimia dalam tubuh malchluk hidup hanxa dapat berlangsung pada harga $\mathrm{pH}$ tertentu. Oleh barena itu, cairan tubuh harus merupakan laxutan penvangga, agar pH senantiasa konstan ketika reaksi metabolisme berlangsung. Kegunaan larutan penvangga tidalk hanva terbatas pada tubuh malshluk hidup. Bealssi-reaksi kimin di laboratorium dan di bidang industri juga banvals menggunakan larutan penxangga
27 question criteria using a scale of 1-4. The results of the validation assessment of 3 validators get a percentage of $94.46 \%$ which means it is included in the very valid criteria. This shows that LKPD developed is suitable to be used as a learning media.

At this stage also obtained criticisms and suggestions that are useful for improving LKPD that have been prepared previously. Criticism and suggestions obtained form the basis for revisions to improve LKPD. Revisions made include: (1) revision on the LKPD cover, (2) design of the LKPD content page, and (3) appearance on the "Mathematical Logical Zone" problem.

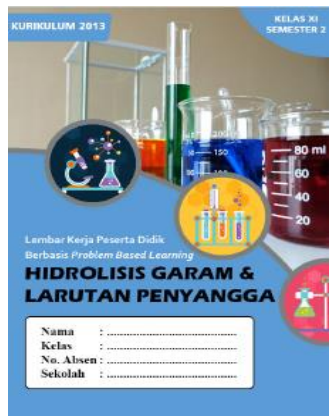

(a)

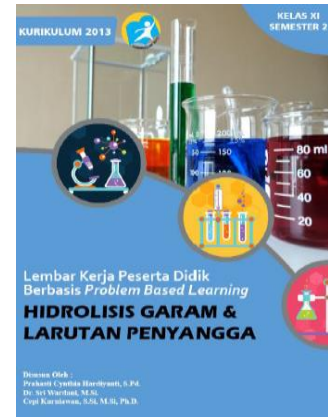

(b)
Figure 1. a) Display of initial cover design, b) Display of revised cover results

In the initial design the LKPD cover section displays background images of various types of latutan depicting the material namely salt hydrolysis and buffer solution by having an identity box background picture for the students presented in Figure 2 (a). But according to the cover validator it is not necessary to include an identity box for students, but rather the identity of the writer presented in Figure 2 (b).

\section{Fase 1. Orientasi Masalah}

Bacalah supitikan attikel berikut!' Mengapa buah dalam kemasan kaleng awet?

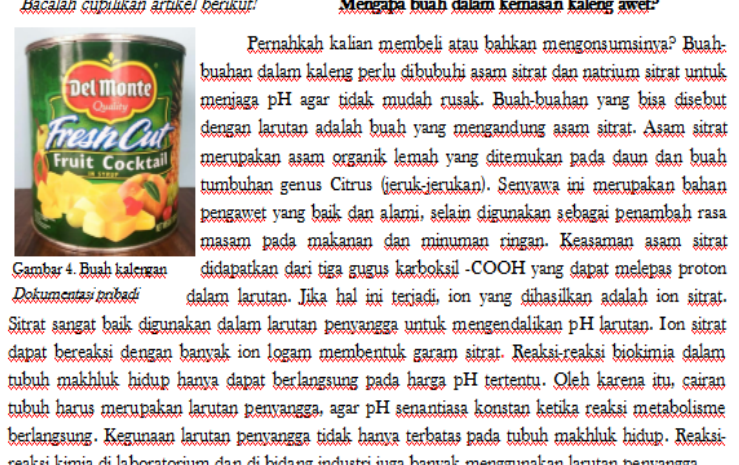
reakssi kimia di laboratorium dan di bidang industri juga banvals mengeunakan larutan penvangga.

Figure 2. a) Display of initial LKPD contents, b) Display revised LKPD contents 
In the initial design the contents of the LKPD display a border picture or broken frame on each LKPD page presented in Figure 2 (a). Based on the validator's evaluation, the frame is unclear and must

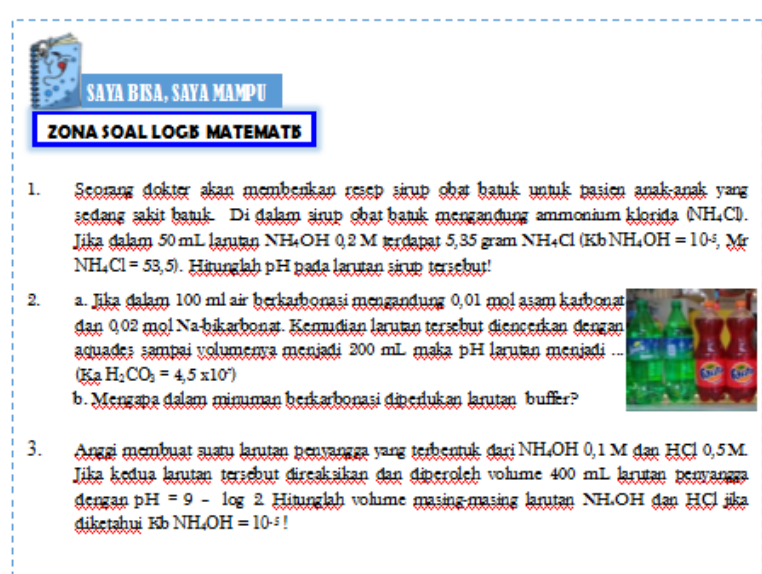

(a) be replaced with a thick border. In addition, the pictures presented at the LKPD must be in the form of pictures or personal documentation to avoid plagiarism from other people's images.

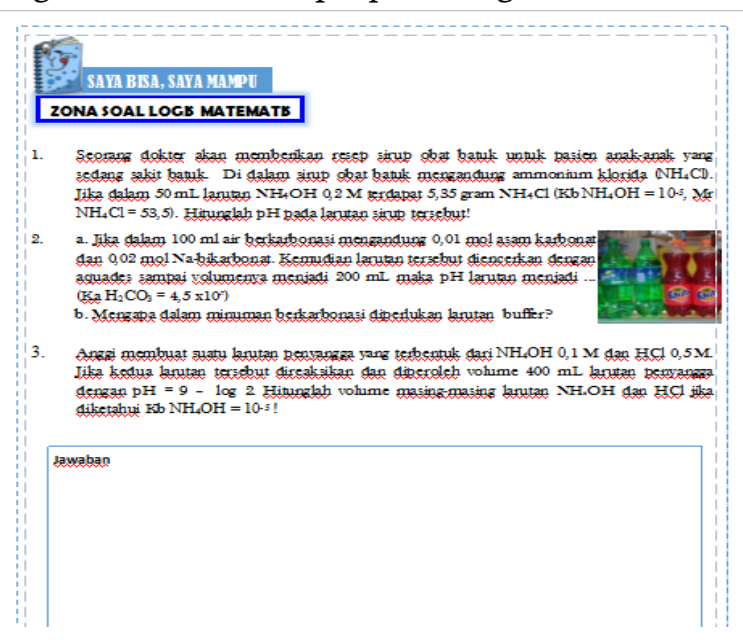

(b)

Figure 3. a) Display of the Practice Exercise, b) Display of the revised Problem Exercise

In the initial design the "Mathematical Logical Zone" problem section presents the practice questions presented in Figure 3 (a). Based on input from the validator, it is better after the question exercise is given space for students to write answers to the question exercise presented in Figure 3 (b).

After the validation and revision phases are carried out on all research tools the next step is to conduct a limited trial. Limited trials are conducted to find out and find deficiencies, weaknesses, obstacles and obstacles that may occur during the learning process. The next stage is a large-scale trial to determine the effectiveness and practicality criteria of LKPD. The effectiveness of LKPD was measured using 2 criteria for increasing mathematical logical intelligence and classical completeness of students. The questions used for the test were tested for reliability with Cronbach alpha and the results obtained were 0.887 , including very high criteria. The results showed that there were 31 students of the large-scale trial class thoroughly and 5 students of the incomplete which showed a percentage of completeness of $86.11 \%$. Mastery learning can be seen from the results of the students' post test compared to KKM 70. A total of 5 students did not complete the study because the post test questions used were in the form of description questions that required the ability to think logically and analytically. Although there are 5 students not completing learning but by using the formula $\mathrm{N}$-gain it is found that there are 11 students who can achieve high levels of achievement, 23 students with moderate levels of achievement, and 2 students who get low. Calculations for increasing mathematical logical intelligence indicators are presented in Table 5.

Table 5. Level of N-Gain Achievement of Mathematical Logical Intelligence Tests

\begin{tabular}{lll}
$\begin{array}{l}\text { Indicator of Mathematical } \\
\text { Logical Intelligence }\end{array}$ & $\langle g\rangle$ & Criteria \\
\hline Thinking patterns & 0.53 & Medium \\
Logical analysis & 0.50 & Medium \\
Problem solving & 0.58 & Medium \\
Calculation process & 0.70 & Medium \\
Mathematical operations & 0.63 & Medium \\
\hline
\end{tabular}

Testing the improvement of mathematical logical intelligence of students is done using the ttest formula. Based on the results of data analysis, it was found that there was a significant increase in mathematical logical intelligence from pre-test to post-test. This significant increase in mathematical logical intelligence is a cause-and-effect relationship with students' positive responses to the LKPD used. This is in line with research conducted by (Fauzi \& Manowati, 2018) that students with good mathematical logical intelligence can work through problem-based learning steps well. Positive responses of students can be used as a benchmark that students feel more comfortable with the LKPD used in the learning process. 
Students are more active in identifying and searching for information needed to solve problems in chemistry (Abanikannda, 2016). Most of the attention of students will be focused on the learning process because of students' interest in LKPD so that they will not get bored quickly towards learning so that mathematical logical intelligence can increase. This is in accordance with (Wardani et al., 2013) that learning chemistry includes thinking to solve problems, analyzing data all of which require mathematical logical intelligence.

The practicality of LKPD was measured based on the results of the questionnaire responses to the learning process that took place with the developed LKPD. Based on this explanation it can be concluded that the results of the questionnaire analysis of responses to LKPD developed by $77.78 \%$. The data can be said to be practical with a level of practicality with a very good response. In the LKPD that was developed there was material that connected the material being studied with everyday life.

In addition, in the LKPD there are also materials and questions that can stimulate students to be actively involved in the learning process. The PBL model developed can train students to analyze problems, make decisions from various points of view, be more thorough, careful and logical (Oktaviana et al., 2016). The components contained in PBL-based LKPD such as instruction in group work, orientation to problem examples, problem solving steps, and mathematical logical intelligence of students make it easy for teachers to actively involve students in the learning process.

The results of the questionnaire stated that nearly half of the students chose responses that were very amenable and agreed. This can be seen from the activeness, enthusiasm, ways of solving problems and curiosity of students. The results of the questionnaire analysis of student responses can be seen in Figure 4.

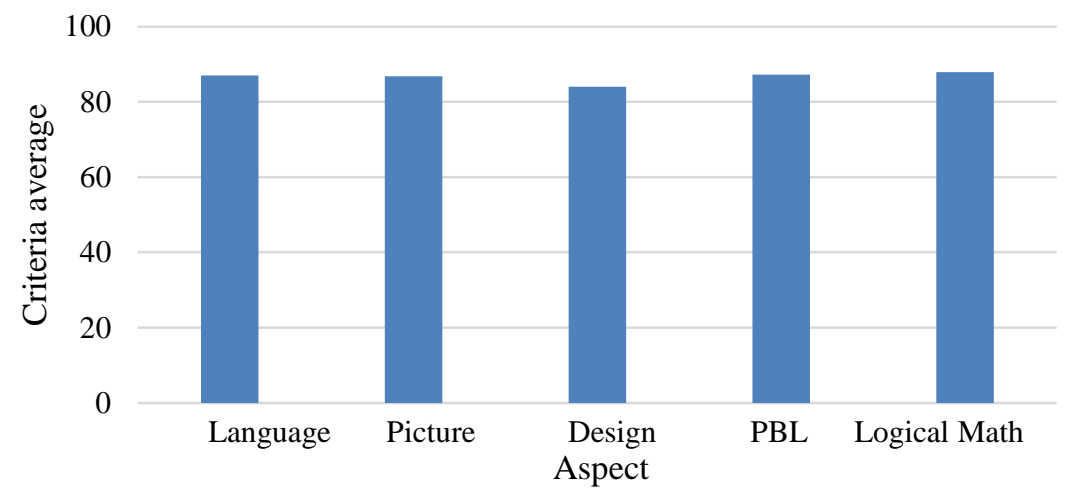

Figure 4. Graph of Analysis Results of Large-Scale Test Students' Responses

Based on the results of research and discussion shows that Problem Based Learning based learning LKPD results> $75 \%$ response from students in each aspect of assessment. This indicates that the results of students' responses in general to PBL-based LKPD showed very good criteria. Most of the attention of students will be focused on the learning process if students are already interested in learning so that they will be more active and give a positive response. This is in line with the statement that the use of PBL-based LKPD can increase students' motivation and confidence in group learning (Ayyildiz \& Tarhan, 2018). Learning will feel more fun and make students want to know more about the material being studied.

\section{CONCLUSION}

Based on the analysis of the results of research and discussion conclusions can be drawn: (1) the results of the validation of PBL-based learning media PBL hydrolysis material developed obtained very valid criteria for use as a learning medium with a percentage of validity according to material experts at $94,38 \%$ and validity according to media experts $94,46 \%$, (2) the results of the increase in pretest posttest mathematical logical intelligence were at $\mathrm{N}$-gain 0,56 or in the medium category, and (3) the results of the questionnaire analysis after using PBL-based LKPD were at a percentage of $77,78 \%$ in the very category well. 


\section{REFERENCES}

Abanikannda, M. O. (2016). Influence of Problem-Based Learning in Chemistry on Academic Achievement of High School Students in Osun State, Nigeria. International Journal of Education, Learning and Development, 4(3), 55-63.

Alejandro, R., Rosario, C., \& Juan, B. (2010). Problem Based Learning (Pbl): Analysis Of Continuous Stirred Tank Chemical Reactors With A Process Control Approach. International Journal of Software Engineering \& Applications (IJSEA), 1(4), 54-73.

Amstrong, T. (2013). Kecerdasan Multiple di Dalam Kelas. Jakarta: PT. Indeks.

Andriyantin, R., Rosidin, U., \& Suana, W. (2016). Pengembangan Lembar Kerja Siswa Model Problem Based Learning Materi Suhu-Kalor. Jurnal Pembelajaran Fisika, 4(1), 39-50.

Asiyah, S., Mulyani, S., \& Nurhayati, D. (2013). Penerapan Model Pembelajaran Learning Cycle 5E Berbantuan Macromedia Flash Dilengkapi LKS Untuk Pokok Bahasan Zat Adiktif Dan Psikotropika Kelas VIII. Jurnal Pendidikan Kimia, 2(2), 56-65.

Ayyildiz, Y. \& Tarhan, L. (2018). Problem-Based Learning in Teaching Chemistry: Enthalpy Changes in Systems. Research in Science \& Technological Education, 36(1), 1-20.

Boncel, W., Eny, E., \& Rody, P. S. (2017). Deskripsi Kesalahan Siswa Dalammenyelesaikan Soal-Soal Hidrolisis Garam Di Kelas XI IPA SMA Katolik Talino. Jurnal Pendidikan Dan Pembelajaran Khatulistiwa, 6(12), 1-7.

Etiubon, R. U. \& Ugwu, A. N. (2016). Problem-Based Learning and Students Academic Achievement on Thermodynamics ( A case study of University of Uyo , Akwa - Ibom state, Nigeria ). Journal of Research \& Method in Education (IRME), 6(5), 3641.

Fauzi \& Manowati. (2018). Hubungan Antara Kecerdasan Logis Matematis dan Kedisiplinan Belajar Siswa SD Negeri 1 Pagar Air Kabupaten Aceh Besar. Jurnal Pesona Dasar, 6(1), 55-62.

Gardner, H. (2003). Kecerdasan Majemuk : teori dalam Praktek. Batam: Interaksara.

Haryani, S., Astiningsih, A. D., Supardi, K. I., \& Kurniawan, C. (2017). Construction of Metacognition Skills Through Students ‘ Worksheet with Problem Based Learning Approaches. In 11th Joint Conference on Chemistry in conjunction with 4th Regional Biomaterial Scientific Meeting (Vol. 2, pp. 37-41).

Lazear, D. (2004). Higher-Order Thingking the Multipple Intelligences Way. Chicago: Zephir Press.
Mariani, S. \& Kusumawardani, E. D. (2014). The Spatial Ability in Grade VIII on Geometry Subject Matter. International Journal of Education and Research, 2(8), 531-548.

Oktaviana, I. A., Agung, N. C., \& Utami, B. (2016). Upaya Peningkatkan Kemampuan Berpikir Kritis Dan Prestasi Belajar Siswa Melalui Penerapan Model Pembelajaran Problem Based Learning (PBL) Dilengkapi Modul Pada Materi Kelarutan Dan Hasil Kali Kelarutan Kelas XI SMA Negeri 1 Gondang Tahun Pelajaran 2014. Jurnal Pendidikan Kimia (JPK), 5(1), 143-152.

Prastowo, A. (2011). Panduan Kreatif Membuat Bahan Ajar Inovatif: Menciptakan Metode Pembelajaran yang Menarik dan Menyenangkan. Yogyakarta: Diva Press.

Purnomo, S. \& Novita, D. (2018). Melatihkan Kecerdasan Logis Matematis Pesertadidik Melalui Model Pembelajaran Kooperatif Tipe Jigsaw Pada Materi Laju Reaksi Kelas XI SMA Negeri 1 Krian Sidoarjo. Unesa Journal of Chemistry Education, 7(2), 136-142.

Ristiyani, E. \& Evi, S. B. (2016). Analisis Kesulitan Belajar Kimia Siswa Di SMAN X Kota Tangerang Selatan. Jurnal Penelitian Dan Pembelajaran IPA, 2(1), 18-29.

Riyani, A. F., Kusumo, E., \& Harjito. (2017). Pengembangan Lembar Kerja Siswa Berpendekatan Inkuri Terbimbing pada Konsep Kelarutan. Jurnal Inovasi Pendidikan Kimia, 11(2), 2008-2019.

Rosita, A., Sudarmin, \& Putut, M. (2014). Perangkat Pembelajaran Problem Based Learning Berorientasi Green Chemistry Materi Hidrolisis Garam Untuk Mengembangkan Soft Skill Konservasi Siswa. Jurnal Pendidikan IPA Indonesia, 3(2), 134-139.

Surya, W. P. \& Holiwarni, B. (2017). Development Of Worksheet Based Problem Based Learning On The Topic Hydrocarbon Of Senior High School. Jurnal Online Mahasiswa, 4(1), 1-12.

Tarhan, L. \& Acarsesen, B. (2013). Problem Based Learning In Acids And Bases: Learning Achievements And Students' Beliefs. Journal of Baltic Science Education, 12(5), 565-578.

Thiagarajan, S. (1974). Instructional Development for Training Teachers of Exceptional Children: A Sourcebook. Indiana: Bloomington Indiana.

Wardani, S., Permanasari, A., Kadarohman, A. \& Buchori. (2013). Kecerdasan Logical Mathematics Berbasis Aktivitas Inkuiri Laboratorium. Jurnal Inovasi Pendidikan Kimia, 7(2), 1129-1138. 